\title{
PERMODELAN KARAKTERISTIK BIODIESEL DARI MINYAK JELANTAH
}

\author{
${ }^{1)}$ Ahmad Hanafie, ${ }^{2)}$ Andi Haslinah, ${ }^{3)}$ Qalaman, dan ${ }^{4)}$ Akbar Made \\ ${ }^{1,2)}$ Dosen Program Studi Teknik Industri Fakultas Teknik Universitas Islam Makassar \\ ${ }^{3)}$ Mahasiswi Program Studi Teknik Industri Universitas Islam Makassar \\ Jl. Perintis Kemerdekaan Km 9 No 29 Kampus UIM, Telp 0411-588-167 \\ Email : ${ }^{1)}$ ahmadhanafie.dty@uim-makassar.ac.id, ${ }^{2)}$ haslinah.dty@uim-makassar.ac.id,
}

\begin{abstract}
ABSTRAK
Penelitian ini bertujuan untuk membuat biodiesel dari minyak jelantah yang diperoleh dari produsen gorengan dengan dua tahapan esterifikasi dan transesterifikasi, hasil akhir dari biodiesel kemudian di uji melalui 3 karakteristik sederhana yaitu densitas, viskositas dan Asam Lemak Bebas Produk biodiesel, Densitas hari pertama $882 \mathrm{~kg} / \mathrm{m} 3$, hari ke 15 adalah $889 \mathrm{~kg} / \mathrm{m} 3$ dan hari ke 30 adalah $889 \mathrm{~kg} / \mathrm{m} 3$. Viskositas hari pertama adalah $5.43 \mathrm{cst}$, hari ke 15 adalah $5.72 \mathrm{cst}$, dan hari ke 30 adalah 5.95 cst, FFA hari pertama $0.28 \%$, hari ke 15 adalah $0.31 \%$ dan hari ke 30 adalah $0.40 \%$.
\end{abstract}

Kata kunci : Biodiesel, Minyak Jelantah, Esterifikasi Dan Trasesterifikasi

\section{PENDAHULUAN}

\subsection{Latar Belakang}

Indonesia dikenal dunia memiliki sumber daya alam (SDA) yang melimpah, terutama minyak bumi dan gas alam. Hal ini yang menjadikan Indonesia memanfaatkan sumber daya alam tersebut dalam jumlah yang besar untuk kesejahteraan masyarakatnya. Dewasa ini kita kerap kali mendengar tentang istilah krisis energi, hal ini disebabkan karena semakin bertambahnya industri yang memerlukan konsumsi bahan bakar minyak yang semakin banyak. Seperti yang telah kita ketahui bahwa minyak bumi dan gas alam adalah salah satu unrenewable resource, sehingga semakin lama persediaan minyak bumi dan gas akan semakin menipis.

Dari permasalahan di atas menjadikan kita harus berpikir bagaimana caranya untuk mengganti SDA tersebut dengan sumber daya yang lebih murah dan tepat guna. Sebagai jawaban dari permasalahan tersebut adalah bioenergi. Bioenergi sendiri merupakan sumber daya alternatif yang dapat digunakan berulang-ulang, untuk mengganti sumber daya fosil yang banyak digunakan di Indonesia saat ini. Biodiesel dapat terbuat dari minyak nabati maupun minyak hewani. Pemanfaatan bahan dari minyak nabati salah satunya adalah limbah minyak goreng atau minyak jelantah merupakan bahan alternatif yang dapat digunakan sebagai bahan bakar. Keuntungan lain dari pemanfaatan minyak goreng bekas ini adalah meminimalisir pencemaran lingkungan akibat pembuangan minyak goreng bekas yang dapat dijumpai di setiap rumah-rumah, penjual gorengan dan tempat-tempat lain pengahasil minyak jelantah. Jika tidak ditangani dan tidak diupayakan pencegahannya maka akan terjadi tumpukan-tumpukan limbah minyak goreng bekas. Karena minyak jelantah bersifat karsinogenik yang tidak baik untuk kesehatan, akan mengakibatkan keracunan dalam tubuh dan berbagai macam penyakit, misalnya diarhea, pengendapan lemak dalam pembuluh darah, kanker dan menurunkan nilai cerna lemak sehingga minyak jelantah lebih baik digunakan maupun didaur ulang sebagai bahan baku pembuatan biodiesel.

\subsection{Rumusan Masalah}

Berdasarkan latar belakang diatas dapat dirumuskan masalah :

1. Bagaimana Pembuatan Biodiesel Dengan Dari Minyak Jelantah?

2. Bagaimana Kualitas Biodiesel Dari Minyak Jelantah? 


\subsection{Tujuan Penelitian}

Adapun tujuan dari penulisan makalah Pembuatan Biodiesel dari Minyak Jelantah ini adalahsebagai berikut :

1. Untuk Mengetahui Proses Pembuatan Biodiesel Dari Minyak Jelantah

2 Untuk Mengetahui permodelan Kualitas/karakteristik Biodiesel dari minyak Jelantah Sesuai Standar SNI.

\subsection{Batasan Masalah}

Agar Penelitian ini dapat dilakukan lebih fokus, sempurna dan mendalam maka penulis memandang penelitian yang diangkat perlu dibatasi variabelnya. Oleh sebab itu, penulis membatasi diri hanya berkaitan dengan "pembuatan biodiesel dari minyak jelantah dengan experimen skala kecil yang menyangkut karakteristik biodiesel yaitu density,viskositas dan FFA(asam lemak bebas)".

\subsection{Manfaat Hasil Penelitian}

1. Mampu memberikan wawasan tentang pemanfaatan limbah, dalam hal ini yaitu minyak goreng bekas/jelantah.

2. Dapat memberikan pengetahuan tentang pembuatan biodiesel dari minyak jelantah dan manfaat pembuatannya.

\section{METODOLOGI PENELITIAN}

\subsection{Alat dan Bahan}

Alat yang digunakan adalah Labu Leher Tiga1000mL, Thermometer,Kondensor,Hotpla te,Statif Dan Klem(standar), Gelas Ukur 10 $\mathrm{mL}, 100 \mathrm{~mL}, 250 \mathrm{~mL}$, Cawan Petri,Gelas Piala 200 mL, 500 mL,Bulp Pipet Skala,Pipet Gondok $25 \mathrm{~mL}$, Penjepit Tabung,Corong Pisah $500 \mathrm{~mL}$ Corong Biasa (standar),Erlenmeyer Filter 1000 mL,Pompa Vakum, Corong Buchner, Kaki 3, Piknometer, Magnet Stirrer, Bahan yang digunakan ; Minyak Jelantah, Metanol, $\mathrm{H} 2 \mathrm{SO} 4, \mathrm{KOH}$

\subsection{Prosedur Penelitian}

\subsubsection{Pembuatan Biodiesel}

Dalam Proses Pembuatan Biodiesel hal yang harus diperhatikan adalah menyiapkan Semua Alat Dan Bahan Yang Akan Digunakan, Selanjutnya Setelah menyiapkan alat dan bahan kemudian Peralatan Refluks Dirangkai dengan hati hati, karena segala proses pencampuran bahan terjadi di dalam alat refluks maka sangat perlu memperhatikan detail dalam merangkai dengan baik, setelah alat refluks selesai dirangkai masuk kepada tahapan Penimbangan beberapa bahan, yaitu minyak goreng $250 \mathrm{~g}$ sebagai bahan utama, methanol $70 \mathrm{~mL}$, dan $\mathrm{H} 2 \mathrm{SO} 4$ sebanyak $1 \mathrm{~mL}$, Setelah itu di masukkan semua bahan yang telah ditimbang tadi ke dalam labu leher tiga , Masuklah ke tahapan Esterifikasi / merefluks campuran, pada tahapan ini kita menjaga bahan tetap pada temperatur $50-60{ }^{\circ} \mathrm{C}$ yang tertera pada thermometer yang terpasang pada rangkaian refluks dengan kecepatan pengadukan konstan, 300-500 rpm dapat diatur pada hotplate. Proses refluks Pemanasan campuran ini dilakukan selama 50-60 menit sebelum masuk ke tahapan transesterifikasi.

Pada tahapan proses transesterifikas i hal yang pertama kita lakukan adalah menimbang $\mathrm{KOH}$ sebanyak 1.25 gram kemudian di masukkan ke dalam gelas piala lalu pipet pula metanol sebanyak $70 \mathrm{~mL}$ di masukkan kedalam gelas piala yang berisi $\mathrm{KOH}$ tadi, kemudian campuran $\mathrm{KOH}$ dan Metanol (Kalium Metanolat) di masukkan Kedalam Metil Ester dari Hasil esterifikasi yang telah dilakukan sebelumnya, Sama halnya proses esterifikasi pada tahapan transesterifikasi kita kembali Merefluks campuran pada temperatur $50-55{ }^{\circ} \mathrm{C}$ dengan kecepatan pengadukan konstan, 300-500 rpm selama 60 menit. Setelah tahapan transesterifikasi selama 60 menit, kita telah mendapatkan dua campuran yang terpisah yaitu metil ester dan gliserol, Pisahkan metil ester dan gliserol dengan menggunakan corong pisah, Metil ester adalah biodiesel namun belum murni atau masih perlu dilakukan penetralan hingga $\mathrm{PH}$ metil ester mendekati PH 7 (netral) dengan penambahan zat asam dan basa, pengecekan menggunakan kertas $\mathrm{PH}$, langkah pemurnian selanjutnya di lakukan pencucian metil ester dan zat-zat pengotor seperti sisa methanol, sisa katalis alkalin, gliserol dan sabun dengan mencampurkan aquadest yang telah di panaskan sebanyak $50 \mathrm{~mL}$ kedalam corong pisah, lalu di pisahkan dan treatment ini dilakukan sebanyak $3 \mathrm{x}$, tahapan terakhir 
adalah memisahkan campuran dan di masukkan kedalam gelas piala dipanaskan pada suhu $110{ }^{\circ} \mathrm{C}$ untuk menghilangkan sisa air selama pencucian tadi.

\subsubsection{Menghitung Massa Jenis Biodiesel}

1. Timbang piknometer kosong yang telah bersih dan kering

2. Isi piknometer kosong dengan biodiesel sampai penuh dan tutup

3. Keringkan bagian luar piknometer dengan lap/tissue

4. Timbang Piknometer + Biodiesel

5. Hitung massa jenis Biodiesel

\subsubsection{Menghitung Viskositas}

1. Masukkan Biodiesel kedalam alat viskositas

2. Masukkan bola kedalam viskosistas yang berisi biodiesel, tapi sebelumnya dilakukan terlebih dahulu :

a) Pengukuran massa bola, dengan cara timbang bola

b) Pengukuran jari-jari (diameter) bola, dengan menggunakan jangka sorong

c) Pengukuran volume bola, dengan cara memasukkan bola kedalam gelas ukur kecil yang berisi aquades, lalu hitung selisih aquades sebelum dimasukkan bola dan sesudah dimasukkan bola hingga diketahui volumenya.

d) Setelah dimasukkan bolanya, hitung viskometer bola jatuh dengan menekan stopwatch pada saat bola sampai tanda garis yang ditentukan dan matikan jika bolanya sampai pada tanda garis bawah yang ditentukan.

e) Catat waktu yang digunakan, dan ulangi percobaan sebanyak 3 kali kemudian hitung rata-rata waktu yang digunakan

\section{ANALISA DAN PEMBAHASAN}

Massa jenis biodiesel yang dihasilkan (max $850-890 \mathrm{~kg} / \mathrm{m}^{3}$ ).Pada gambar grafik 4.1 Densitas menunjukkan perbandingan berat jenis per satuan volume. Minyak dengan densitas tinggi memiliki kemampuan bakar yang rendah.

Dari grafik dapat diketahui bahwa densitas dari minyak jelantah adalah hari ke 1:959 kg/m3, hari ke 15:974 kg/m3 dan hari ke $30: 974 \quad \mathrm{~kg} / \mathrm{m} 3$ sedangkan untuk Biodisesel hari pertama $882 \mathrm{~kg} / \mathrm{m} 3$, hari ke
15 adalah $889 \mathrm{~kg} / \mathrm{m} 3$ dan hari ke 30 adalah $889 \mathrm{~kg} / \mathrm{m} 3$.Dapat dilihat bahwa sampel biodiesel yang di hasilkan dari penelitian ini mempunyai nilai densitas yang lebih baik dari nilai densitas dari minyak jelantah sebelum diproses menjadi biodiesel, dan sesuai dengan standar karakteristik nilai densitas biodiesel yang mempunyai batasan nilai densitas antara $850 \mathrm{~kg} / \mathrm{m} 3$ sampai 890 $\mathrm{kg} / \mathrm{m} 3$

Standar SNI biodiesel yang ditetapkan pemerintah yaitu 2,3 - $6 \mathrm{cSt}$. Viskositas mempunyai peranan yang sangat penting dalam proses penginjeksian bahan bakar. Viskositas yang terlalu rendah dapat menyebabkan kebocoran pada pompa injeksi bahan bakar dan kalau terlalu tinggi dapat mempengaruhi kerja cepat alat injeksi dan mempersulit pengabutan bahan bakar .

Viskositas biodiesel hasil penelitian ini lebih besar dibandingkan dengan yang didapatkan sebesar 4,53 cSt namun tetap masuk standart SNI. Bahan baku yang digunakan juga sama minyak goreng bekas tetapi sumber minyak goreng bekasnya berbeda. Perbedaan lainnya adalah jenis katalis yang digunakan. menggunakan $\mathrm{NaOH}$ sebagai katalis dalam reaksi transesterifikasi.

Dari gambar grafik dapat di lihat nilai viskositas dari sampel biodiesel hari pertama adalah 5.43 cst, hari ke 15 adalah 5.72 cst, dan hari ke 30 adalah 5.95 cst. Bila dibandingkan dengan nilai viskositas dari minyak jelantah sebelum diproses menjadi biodiesel yaitu hari pertama adalah $6.41 \mathrm{cst}$ hari ke 15 adalah 6.62 cst, dan hari ke 30 adalah 6.49 cst . nilai viskositas dari sampel biodiesel hasil pencucian dari penelitian ini sudah dapat dikatakan bahwa sampel biodiesel sudah lebih encer dibandingkan minyak jelantah, dan telah memenuhi standar biodiesel yang mempunyai batasan nilai viskositas sebesar 2,3 cst $-6,0$ cst,

Kadar free fatty acid (FFA) yang dikenal dengan kadar asam lemak bebas pada minyak jelantah bahan baku biodiesel, Kadar FFA minyak jelantah yang relatif tinggi perlu diturunkan melalui proses esterifikasi dengan bantuan katalis asam $\left(\mathrm{H}_{2} \mathrm{SO}_{4}\right)$. minyak dengan kadar FFA tinggi (>2\%) tidak dapat secara langsung diproses transesterifikasi, 
tetapi harus diturunkan kadar FFAnya melalui esterifikasi. perlu dilakukan reaksi dua tahap yaitu esterifikasi dan transesetrifikasi dalam proses produksi biodiesel untuk dapat menghasilkan hasil yang baik. Apabila minyak dengan kadar FFA tinggi langsung diproses transesterifikasi dengan katalis basa $(\mathrm{KOH})$ akan terbentuk sabun yang dikenal dengan reaksi penyabunan/reaksi saponifikasi. Reaksi saponifikasi terjadi antara asam lemak bebas (FFA) dengan katalis basa, sehingga efektifitas katalis akan menurun karena sebagian katalis bereaksi dengan asam lemak .Esterifikasi dengan katalis asam diperlukan untuk menurunkan kadar FFA sebelum transesterifikasi dilakukan.

Kadar FFA pada standar spesifikasi biodiesel adalah maks $0.8 \%$,sehinnga dapat di lihat pada gambar grafik dari minyak jelantah sebelum diproses menjadi biodiesel yaitu hari pertama adalah $0.88 \%$, hari ke 15 adalah $0.89 \%$, dan hari ke 30 adalah $0.94 \%$. Sedangkan dari sampel biodiesel didapatkan hasil kadar FFA hari pertama $0.28 \%$,hari ke 15 adalah $0.31 \%$ dan hari ke 30 adalah $0.40 \%$.Dari data yang diperoleh, dapat diketahui bahwa sampel biodiesel dari minyak jelantah dari penelitian ini memiliki kualitas karakteristik kadar FFA yang memenuhi standar SNI biodiesel.

\section{PENUTUP}

\section{Kesimpulan}

Dari hasil dan pembahasan maka dapat diambil kesimpulan sebagai berikut:

1. Minyak jelantah melalui proses esterifikasi dan transesterifikasi dengan menggunakan katalis $\mathrm{KOH}$ dapat di buat menjadi bahan bakar tepat guna (Biodiesel)

2. Hasil pengujian karakteristik biodiesel dari minyak jelantah dengan katalis $\mathrm{KOH}$ adalah sebagai berikut

a. Densitas hari pertama $882 \mathrm{~kg} / \mathrm{m} 3$, hari ke 15 adalah $889 \mathrm{~kg} / \mathrm{m} 3$ dan hari ke 30 adalah $889 \mathrm{~kg} / \mathrm{m} 3$.

b.Viskositas hari pertama adalah $5.43 \mathrm{cst}$, hari ke 15 adalah 5.72 cst, dan hari ke 30 adalah 5.95 cst
c.FFA hari pertama $0.28 \%$, hari ke 15 adalah $0.31 \%$ dan hari ke 30 adalah $0.40 \%$.

\section{DAFTAR PUSTAKA}

Ahmad Hanafie, A.Haslindah, Muh. Fadhli (2015), Pengembangan Mesin Perontok Padi (Combine Harverter) yang Ergonomis Untuk Meningkatkan Produksi, Prosiding Seminar Nasional Tahunan Teknik Mesin Indonesia-XIV, Banjarmasing, 7-8 Oktober 2015.

Ahmad Hanafie, Hammada Abbas, Lawalenna, Sumarni Hami (2016), Study Of Vehicles Utilities And LoadUnloading Facilities Of City Public Transport Based On Ergonomics Assessment, International Journal of Advances in Scientific Research and Engineering (ijasre.net) Volume-1, Issue3, December - 2016.

Badan Pengkajian dan Penerapan Teknologi. 2015. Outlook Energi Indonesia 2015. Badan Pengkajian dan Penerapan Teknologi. Jakarta.

Badan Standar Nasional Indonesia. 2015. Biodiesel. www.bsn.go.id. Jakarta ( 7 september 2017).

Boedoyo, M. S. 2006. Teknologi Proses Pencampuran Biodiesel dan Minyak Solar di Indonesia. Dalam Prospek Pengembangan Bio-fuel sebagai Substitusi Bahan Bakar Minyak. hlm. 51 -61. jakarta.

Burt, B.G. and W.C. Meuly. 1944. Preparation of Detergent. US Patent Office. 2,360,844.

Canaki, M. And Van, Gerpen JH. 1999. Biodiesel production via acid catalysis. Trans.of ASAE 42(5),p:1203-1210

Desiyana, V. 2014. Pengaruh Rasio Molar dan Waktu Reaksi Terhadap Hasil dan Mutu Biodiesel dari Minyak Jelantah Melalui Transesterifikasi yang Dibantu Gelombang Ultrasonik. Skripsi. Universitas Lampung. Bandar Lampung. hlm 105.

Encinar, J.M., J.F. Gonzalez, and A.R. Reinares. 2005. Biodiesel from Used

Evy Setiawati Fatmir dan Edwar,2012," Teknologi pengolahan biodiesel dari 
minyak goreng bekas dengan teknik mikrofiltrasi dan transesterifikasi sebagai alternatif bahan bakar mesin diesel",Jurnal Riset Industri Vol. VI No. 2, 2012, Hal. 117-127

Fajar, B. dan E. Widayawati. 2011. Investigasi Pengaruh Kavitasi Ultrasonik Pada Transesterifikasi Biodiesel (Skala Lab) untuk Pengembangan Ultrasonik Mobile Reactor. Prosiding Seminar Nasional Sains dan Teknologi ke-2: A.7A.12.

Freedman, B., Pryde, E.H., Mounts. T.L., 1984. Variables Affecting the Yields of Fatty Esters from Transesterfied Vegetable Oils. Jurnal of the American Oil Chemists Society. Vol. 61: 1638 1643.

Haryanto, B. 2002. Bahan Bakar Alternatif Biodiesel (Bagian I. Pengenalan). Universitas Sumatera Utara digital library. Universitas Sumatera Utara. 1 13.

Hardjono, A., 2001, “ Teknologi minyak Bumi “, Gadjah Mada University Press, Yogyakarta

Kuncahyo, P., A. Z. M. Fathallah, dan Semin. 2013. Analisa Prediksi Potensi Bahan Baku Biodiesel Sebagai Suplemen Bahan Bakar Motor Diesel di Indonesia. Jurnal Teknik Pomits. Vol. 2(1): 2301 - 9271.

Mittelbatch, M.; B. Pokits; and A. Siberholtz. 1992. Production and fuel properties of fatty acid methyl ster from used frying oil. In liquid fuel from renewable resources. Proc. of An Alternative Energy Conference, St. Joseph, Mich: ASAE, p:74-78.

Suirta, I.W., 2009, “ Preparasi Biodiesel dari Minyak Jelantah Kelapa Sawit”, Jurnal Kimia,Vo 1.3. No.1, 1-6.

Tiwari, Kumar Alok.; Kumar, Akhilesh; and Reheman; Hifjur. 2007. Diesel production from jatopha oil (Jatropha curcas) with high free fatty acid: an optimized process. Biomass and Bioenergy, 31,P;569-575.

Wang, J.; Ge, X.; Wang, Z.; and Jin, Y. 2001. Experimental studies on the catalytic distillation for hydrolisis of methyl acetate. Chem. Eng. Technol. 24(2);p:155-159.

Wang, Y.; Ou, S.; Liu, P.; Yue, F.; and Tang, S. 2006. Comparision of two differnt process to synthesis biodiesel by waste cooking oil. Mol. Catal. A:Chem 252, p:107-112.

Yingying, Liu; Houfang, Lu; Wei, Jiang; Dongsheng, Li; Shije, Liu; and Bin, Liang. 2012. Biodiesel production from crude Jatropha curcas L. oil with trace acid catalyst. Energy Resources and Environmental Technology, Chinese Journal of Chemical Engineering 20(4),p:740-746.

Suradi, H. Abbas, W. Tjaronge, V. Sampebulu, Estimation of Standard Time in Production of Light Weight Brick Manufacturing Using Ball Mill, International Journal of Advances in Scientific Research and Engineering (ijasre.net), ISSN 2454-8006 Volume-2, Issue-1,January-2016

Suradi, H. Abbas, W. Tjaronge, V. Sampebulu Analysis Standard Time Section 1 of Brick Light Production (Autoclave Aerated Concrete/AAC), International Journal Of Current Research, (www.journalcra.com) ISSN0975-833X, Volume 8, Issue 01, PP.25307-25310, January,2016 